\title{
The use of comic strips as a means of teaching history in the EFL class: Proposal of activities based on two historical comic strips adhering to the principles of CLIL
}

\author{
El uso de tiras cómicas como medio de enseñanza de la historia \\ en la clase de inglés como lengua extranjera: Propuesta de actividades \\ basadas en dos tiras cómicas históricas que se adhieren a los principios \\ de CLIL
}

\author{
Livia Carolina RAVELo \\ Instituto Superior del Profesorado Joaquín V. González \\ (Buenos Aires, Argentina)
}

\begin{abstract}
Teaching English as a second or foreign language in a globalised world imposes constant innovations in methodological frameworks and didactic resources. As a consequence, English should be conceived not only as an object of study but also as the vehicular language to access cultural, sociological, historical as well as other sources of information. This paper is intended to show that the use of comic strips can be regarded as a valid resource to teach history in the EFL classroom with CLIL (content language integrated learning) as the methodological framework. To achieve this goal, activities designed around two historical comics on the fewish Holocaust (Shoah) have been included; these can be used as example and adapted to plan other activities on other historical comics.
\end{abstract}

Key Words: CLIL; bilingual education; comics; history education; instructional materials.

\section{Resumen}

La enseñanza del inglés como segunda lengua o lengua extranjera en un mundo globalizado impone constantes innovaciones en los marcos metodológicos y recursos didácticos. Como consecuencia de ello, el inglés debe concebirse no sólo como un objeto de estudio, sino también como lengua vehicular para acceder a las fuentes culturales, sociológicos, e históricos, así como de otros tipos de información. En este trabajo, se pretende demostrar que el uso de tiras cómicas puede ser considerado como un recurso válido para enseñar historia en el aula de inglés como lengua extranjera con AICLE (Aprendizaje Integrado de Contenidos y Lenguas Extranjeras) como el marco metodológico. Para lograr este objetivo, se han incluido unas actividades diseñadas en dos cómics históricos sobre el Holocausto judio (Shoá); se puede utilizarlas como ejemplos y adaptarlas para planificar otras actividades en otros cómics históricos.

Palabras Claves: AICLE; educación bilingüe; cómics; educación de historia; materiales de instrucción. 


\section{INTRODUCTION}

Teaching English as a second or foreign language in a globalised world imposes constant innovations in methodological frameworks and resources. People around the world are exposed to different kinds of information thanks to the media, television, the internet (among others) and our students are no exception to the rule. Consequently, English should be conceived not only as an object of study but also as the vehicular language to access cultural, sociological, economic, and other sources of information. The inclusion of content in the EFL or ESL classroom seems to be unavoidable. What is more, the selection of content and material seem to play a significant role when borrowing, adapting or designing materials to guarantee the successful teaching of content.

This paper is intended to show that the use of comic strips can be regarded as a valid resource to teach history in the EFL classroom with CLIL (content language integrated learning) as the methodological framework. The reader will find some activities based on comic strips which have been designed following the principles of the CLIL approach, which are expected to be adapted to the characteristics and needs of the teaching contexts where applied and to be taken as an example to plan activities on other historical contents as well.

\section{Use of comics in the EFL classroom}

\section{The language and characteristics of comics}

Reading comics might allow the reader to be completely absorbed in his reading and his imagination can be carried away even against his will. The power of comics relies on the fact that they are entertaining, and their characters are those heroes and heroines we might easily feel identified with. Besides, the power of words and images create a non-conventional atmosphere which help us read non-stop.

When we read comics, the words and the images are interrelated and complement each other in such a way that we can even read texts through images. Words might appear as part of a narration or inside "balloons", when the characters are speaking and also inside "clouds", when they are thinking about something. Steimberg (1977, p.24) claims that words are, in some cases, replaced by simplified mental and conventionalized images, such as the light bulb to indicate a brilliant idea or the little stars which denote pain, among others. What 
is more, the non-conventionalized image allows the reader to make different kinds of interpretations since no explicit message is being said. Consequently, the power of the image relies on the fact that it is capable of connoting as many messages as readers are.

Eco (2005) argues that the comic is an exponent of the mass culture, which establishes its own semantics, in other words, it has specific signs or conventions which make up a language of its own. Speech balloons and boxes are used to indicate dialogue and impart establishing information, while panels, layout, gutters and zip ribbons can help indicate the flow of the story. The use of text, ambiguity, symbolism, design, iconography, literary technique, and other stylistic elements of art help build a subtext of meanings or semantics.

Among the conventions and signs that make up the language of comics, we find the kind of shots, framing, and angles, the line, the presence or absence of colour, among other signs which also shared by other types of genres or languages, such as the television, the cinema, the graphic language (Barbieri, 1993).

Regarding kinds of shots, in the extreme wide shot (EWS) the view is so far from the subject that they are not visible. In the very wide shot (VWS), the subject, even if visible, is not the focus itself since the emphasis relies on placing them in a certain environment. The simple wide shot (WS) shows a subject who takes up the full frame, contrary to the mid shot (MS), which shows some part of them in more detail while still giving an impression of the whole subject. Another shot which allows us to highlight details is the close-up, in which a certain feature or part of the subject takes up the whole frame. The extreme closeup shows extreme details. The cut-in is the shot that shows in detail some part of the subject excepting the face.

Concerning angles, there are a great variety, and their use helps build an interesting, peculiar perspective on the subject that is being framed. The angle selected can allow the reader or the audience (television, cinema) to make different hypotheses on what is being depicted. The common types of angles are: the normal angle, high camera angle, low camera angle, canted angle (on a slant), reverse angle, subjective camera angle (from the point of view of the subject; the way the subject sees things), and objective camera angle (the way an objective party or outsider is supposed to see things). The angle that looks up or down at the object that is being framed (instead of being on the same level) make up the 
so-called tilt shots, which are more dramatic than straight-angle shots. A downward tilt shot is used to observe action over a large area or to create a psychological impression of inferiority or weakness. Conversely, an upward tilt shot lends an impression of superiority, awe, or size.

Barbieri (1993) also comments on the different kinds of lines that are to be found in any comic strip, which have different kinds of meaning. The line itself can represent an object, for example, a cord or the arm of a person in a childlike depiction of a human silhouette. It can also be the contour of an object, which is the case of a circle that represents a ball. The line can be either pure or modulated. The first one is used to draw and delimit objects; consequently, it also allows us to distinguish one object from another. The modulated line adds an extra meaning compared to the pure one. For example, the thin line that delineates the pages of a book reminds us that they are made of paper. The thick line that composes the edge of a table tells us about its thickness and inclination. What is more, the modulated line can also let the reader visualize different textures, materials, shadows and illumination. Finally, the presence and absence of colour will also add several meanings which should be interpreted in each particular comic.

\section{Comics as a valid genre for the transmission of history}

Even though comic strips are said to narrate and represent fiction, they can also be a valid genre in the transmission of real story, which is the case of the socalled historical comics. In his article "Historical emplotment and the problem of truth", Hayden White (1992) argues that in traditional historical discourse there is a crucial difference between the interpretation of historical facts and what is being narrated about them. This difference is based on the existence of a real discourse (as opposed to a fictional one) and a true discourse (contrary to a false one). All interpretations are understood as comments about events, whereas any historical narration is presumed to be inherent to the facts themselves, in other words, historical narrations are claimed to be real as they are based on the critical study and analysis of the historical data derived from the facts.

So, is it possible to transmit history through a genre that presupposes the existence of fiction (which is the case of comic strips)? And, if so, will this narration be as valid as any other historical narration? In "Hecho y figuración en el discurso histórico" (2003), White argues (p. 57) that the Holocaust, for example, 
can be narrated through any kind of genre, including comedy and parody. However, when considering moral and ethical criteria, the selection of certain genres to represent some historical facts might be found disgusting by the audience. Moreover, White reminds us that any representation of the Holocaust is not the Holocaust itself. This understanding might provide a tentative answer to the questions this study poses (and attempts to answer): It is indeed possible for the medium of comic strips to represent historical facts and these representations are as valid as any other which is derived from what might be perceived as more "serious" genres.

\section{The CLIL Approach}

\section{Defining $C L I L$}

CLIL stands for Content and Language Integrated Learning. In Spanish, this approach is known as AICLE (Aprendizaje Integrado de Contenidos y Lenguas Extranjeras), and the corresponding French acronym is EMILE (Enseignement de Matières Par Intégration d'une Langue Étrangère). Defining CLIL is not an easy task since there are different types of CLIL practice. Some definitions which shed light on the understanding of this approach are read as follows:

Content and language integrated learning (CLIL) refers to any dual-focused educational context in which an additional language, thus not usually the first language of the learners involved, is used as a medium in the teaching and learning of non-language content. It is dual-focused because whereas attention may be predominantly on either subject-specific content or language, both are always accommodated. (Marsh, 2002)

CLIL is an approach to bilingual education in which both curriculum content (such as science or geography) and English are taught together. It differs from simple English-medium education in that the learner is not necessarily expected to have the English proficiency required to cope with the subject before beginning study. Hence it is a means of teaching curriculum subjects through the medium of a language still being learned, providing the necessary language support alongside the subject specialism. CLIL can also be regarded the other way around - as a means of teaching English through study of a specialist content. (Graddol, 2006, p. 86)

This so-called "accommodation" (between content being taught and English as the means) which should be achieved and the fact that the student is not 
necessarily expected to have the English proficiency required to cope with the subject before beginning study might be perceived as a real challenge for the English teacher-though it is not an unbeatable obstacle.

The application of CLIL, even if it is not an easy task, is indeed feasible, since there many ways in which the approach can be adapted according to the characteristics of the context, giving rise to weakest versions of the approach in question, which are as valid as the strong version of it (whose context is an immersion school). For example, the language teacher can plan her classes on topics, not purely on linguistic grounds, or the academic year in the language class might consist of a planning of thematic units, which aim at achieving a certain goal. Most important of all are decisions regarding factors such as what to teach precisely, on what grounds the content is to be chosen, materials needed, and time budget. In other words, the CLIL approach requires conscious decisions to be made by the teacher and their superiors/institution.

Concerning curricular variation in CLIL, Coyle, Hood, and Marsh (2010, p.14) enumerate some operating factors to be considered: Teacher availability is crucial, because it is usually the starting point for designing a model and also how the teacher works (individually, in groups) will determine both planning and implementation. The levels of teacher and student target CLIL-language fluency determine the teacher's input and role in the classroom. The amount of time is also of crucial importance since it influences directly on setting of objectives, when the CLIL course will be implemented in the curriculum and the kind of CLIL model that will be adopted. The way in which content and language are integrated-whether language-learning preparation before the CLIL course, language learning is embedded in the CLIL course, or language learning parallel to the CLIL course-influences decision-making on how each is handled within the chosen model. Linking the CLIL course to an out-of-school or extra-curricular dimension, enabling task-based communication with learners in other schools or countries and networking with teachers/visitors from outside the school/country all have an impact on the scale and scope of the model chosen.

Regarding the scale of CLIL, the authors explain that the instruction through the vehicular language can be either extensive or partial. In the first one, the vehicular language is used almost exclusively to introduce, summarize and revise topics, with very limited switches into the first language to explain specific language aspects of the subject and vocabulary items. There is a clear triple focus 
on content, language, and cognition. Content is taught using methods which support language learning and understanding to a greater or lesser extent in lessons. This scaffolded approach is used to introduce new vocabulary and concepts, grammatical use and others in conjunction with the content. This task may be done by a single content teacher, through cooperation with a language teacher, which seems to be highly effective when certain linguistic structures are pre-taught or language may be taught parallel to the content learning in separate language classes. Content relevant language may also be taught by a language teacher who takes responsibility for teaching the content area.

When the instruction is partial, specific content, drawn from one or more subjects, is taught through CLIL according to limited implementation periods (possibly less than five percent of the whole curriculum is taught through CLIL). In such a case, a project-based modular approach is often used and the responsibility for teaching may rest with the content or language teachers, or both. In this instruction, as well as in the extensive one, there is a triple focus on content, language, and cognition. In addition, code switching or translanguaging (systematic switch from one language to another for specific purposes) arises in partial instruction where lessons involve systematic use of both CLIL languages and the first language should be used for specific types of activities. This systematic switch must be based on a planned development of content, language, and cognition. For example, students can use a textbook in their L1 when doing homework in order to build confidence and check comprehension. Other learners may ask for explanations from the teacher in a particular language, beginner CLIL learners may use their L1 to speak to the teacher when problem solving. However, with regards tothe teacher's role, Coyle, Hood, and Marsh emphasise that the CLIL teacher must answer questions and support learners in the vehicular language.

\section{METHODOLOGY}

\section{Description of the target group and their context}

Regarding the sample selected in the process of material design, the activities were designed for a group of five Jewish adolescents (aged 16-17) who attended private English classes three times a week to improve their conversational skills while discussing content from real, authentic sources. These students attended a 
private Jewish secondary school in Buenos Aires, Argentina where the Shoah (Holocaust) is part of the official curricula and where one of the suggested school trips is a visit to the Auschwitz concentration camp in Poland.

The Holocaust is a complex topic for study because the students (in this context) are likely to have ancestors who were either victims or survivors of Nazi Germany, and this might lead students to certain prejudiced values and judgments concerning the topic.

\section{Description of the creative process}

Regarding the process of corpus selection, comic strips which tackle the same topic were selected to make students be able to understand and compare the treatment the same historical component receives in the different sources.

The comic strips were also selected considering the conventions or signs which might trigger some possible reflection, discussion and learning. For example, the planes depicted in any comic strip, the same as the colours chosen, are highly significant because of some possible interpretations that might be aroused. These special features will be specially considered in the creative process of the material design, since images and other signs, when interpreted, could easily become more powerful than words.

\section{Description of the types of materials and activities designed}

For this study, content focused on World War II and the Holocaust (Shoah) was selected. The masterpiece that tackles these topics is Maus (1986) by Art Spiegelman. Some content was also drawn from other excellent comic books that deal with the same topic, such as Yossel (2003) by Joe Kubert.

In the materials designed, language was not the object of primary importance. In other words, the activities were aimed at developing the students' critical perspectives on the subject matter they were supposed to study and eventually comprehend. The cultural component was of paramount importance. Nonetheless, language was sometimes allowed to become the focus of a preactivity so as to avoid possible misunderstandings (for example, specific vocabulary items related to the topic of study).

The use of comic strips in this context was not intended to replace the use of textbooks, journals, or other relevant materials but rather to complement these or as a trigger for further study. The material was intended for inclusion at the 
end of a larger unit devoted to the study of World War II, and of the Holocaust specifically. The students selected are required to study this topic in detail. As this topic is rather controversial, especially because some of the students have ancestors who died in the camps, it was believed that the incorporation of comic strips would help allow them study this topic without experiencing a sort of sentimentalism which might inhibit their approach to certain kinds of sources.

Appendix: CLIL lesson plan provides details of a lesson plan used in this study.

\section{RESULTS}

Students seemed to be involved in the tasks designed. Their interest was mainly based on the fact they were focusing on specific signs from the strips, which could be interpreted in different, valid ways. They were able to read the stories narrated not only through words but also through images, which convey a language of their own. These interpretations gave rise to rich debates.

While doing the activities, three (out of five) students realised they did not know the meaning and origin of the swastika, despite the fact they had previously read vast literature on the Holocaust. The fact of reading about the meaning of this sign motivated them to investigate additional Nazi and neo-Nazi symbolism as well. To achieve this task, they formed two groups that sometimes met to exchange information.

Additionally, they learned that only in Auschwitz were victims' arms tattooed. This question of numbers replacing names allowed them to reflect on the concept of identity, the importance of one's name, and also to pursue further research on concentration camps, which allowed them eventually to discover similar camps in remote places they had never heard of before (for example, in China).

Working with the database of Shoah victims' names made them reflect on the importance of the transmission of memory and the importance of keeping recordss that permit the reconstruction of history. They started looking for some information on Vadlek Spiegelman, the father of Art Spiegelman (author of Maus) and ended up looking for Argentine victims.

When asking students what they thought about the use of comic strips to learn about and discuss the Holocaust, they explained that the comic strips allowed them to talk about this topic about which they had been reading for 
several years (in Spanish and in English) in a peculiar way, for they were concentrating on specific signs, which provided them with a lot of data and which sometimes made them curious about some contents in particular. What is more, they reflected on the fact that just one single sentence, phrase, or word might reveal lots of information and that images might trigger innumerable interpretations. One student added that he felt relaxed not to be obliged to read long texts on this historical event.

Regarding the pictures shown, the learners expressed that they were glad not to have to analise stereotypical images of the Shoah, such as the pile of naked, skinny corpses. The introduction of Spiegelman's mice helped detach the students detached from sentimentalism, melancholy, or sadness.

\section{DISCUSSION}

Teaching the Holocaust is not an easy task. Many feelings, sensations, doubts, or even family memories may arise when studying such a controversial topic. Why the Holocaust happened, the role of both victims and murderers, the concept of the "Aryan race" and of "superior blood", among others, are typical topics that must be tackled and deeply analysed if the main objective is to understand the complexity of this kind of phenomenon.

Dealing with this level of complexity when teaching English as a second language implies making decisions regarding the methodology that will be implemented in the classroom and the materials which are either selected, adapted, or designed to fulfil the objectives of the didactic unit devoted to the topic. The present study suggests the use of comic strips (in this case, about the Holocaust) around which can be designed instructional materials based on the CLIL approach. Even if the activities were designed for a specific group, as in this case, it is suggested that similar kinds of materials would support similar successes with other kinds of groups if adapted appropriately to the students' personal variables and cultural contexts.

The main advantage of working with comics or cartoons is the pleasure of reading a narration that coexists with images. Even if words and pictures could be interpreted in isolation, once put together they recreate a peculiar narration of their own. We read but also devote time to interpreting the images, which provides support for, as well as breaks from, the reading process. 
Comics, a genre which has long been considered a minor genre, are not always expected to illustrate a real story because they are immediately associated with fictional stories. And here, precisely, the challenge begins: the reader is expected to know what signs make up the language of comics, their common interpretations or meanings, and-most important of all-to understand that the same sign can have a meaning of its own, despite all possible generalizations. This is the magical game: being able to interpret a sign in a specific co-text.

If we expect our students to read such signs to learn about history, first they should be trained on the typical signs that make up the language of comics. It is also worth mentioning that the more the reader knows about the cultural content in question (in the case of this study, the Holocaust), the more they will be able to interpret the relevant signs. Sometimes, the presence of a sign that catches our attention obliges us to do some further research, and we end up increasing our knowledge and developing our capacity for critical analysis.

Regarding the instructional design of this study, the activities constitute a form of proposal. There is always place for negotiation with students, especially if they have interest in some topic in particular or even some difficult to understand some cultural contents, in which case the teacher is expected to support them. The activities suggested here adhere to the principles of the CLIL approach in that they enhance peer communication, help develop reading strategies, guide the students' production (both oral and written), and also engage higher cognitive skills, such as recognition, understanding, application of certain procedures, and evaluation (with the purpose of developing the students' critical thinking and judgement). Moreover, the activities are intended to encourage the students to resort to their own creative skills. Finally, the use of a portfolio as a means of evaluation (see Evaluation: Portfolio assessment) allows students to develop all that has been mentioned before at their own space and provide them with opportunities of including some extra material of their interest. Everything that is pertinent to the students' learning about the Holocaust was expected to be part of their portfolios.

Regarding vocabulary related to the subject matter (in this case, the Holocaust), the students were exposed to different sources to aid their acquisition. When it was necessary to recognise, understand, and/or apply specific language, the teacher encouraged students to use dictionaries to clarify their doubts or to confirm some hypothesis of their own. Students in the target 
group selected for the materials designed were seen to acquire a more advanced command of the English language as well as the necessary interpretative skills to infer the meaning of words through context, which is the reason no specific activity was designed with the objective of learning and incorporating vocabulary. Moreover, the specific language related to the Holocaust (for example, final solution, concentration camp, ghetto, gas chamber) is rather simple for such a sample. In the present proposal, new vocabulary as well as other kinds of new language was expected to be deployed in writing assignments as well as in oral activities.

The role of the teacher was also contemplated. In all cases, the teacher had to ensure availability and to become an advisor more than the supreme source of knowledge. Both the teacher and the students enjoyed working together in the challenge of learning cultural contents in the vehicular language.

Finally, it is argued that comics are a suitable and practical genre for facilitating the teaching and learning of history in the CLIL classroom, since they allow students to infer meanings not only through words but also through images, which can trigger immensurable valid interpretations which are likely to be shared when the pedagogical approach (in this case CLIL) encourages peer communication and when content is (as the acronym suggests) the primary focus of the students' learning process.

\section{REFERENCES}

Barbieri, D. (1993). Los lenguajes del cómic. Barcelona, Spain: Editorial Paidós.

Coyle, D., Hood, P., \& Marsh, D. (2010). CLIL: Content and language integrated learning. Cambridge, England: Cambridge University Press.

Eco. U. (2005). Apocalípticos e integrados. Buenos Aires, Argentina: Fábula.

Graddol, D. (2006). English next: Why global English may mean the end of "English as a foreign language”. London, England: The British Council. Retrieved from http://www.britishcouncil.org/learning-research-english-next.pdf

Kubert, J. (2003). Yossel: April 19, 1943. New York City, NY: DC Comics.

Marsh, D. (2002). The relevance and potential of content and language integrated learning (CLIL) for achieving $\mathrm{MT}+2$ in Europe. ELC, 9. Retrieved from http://userpage.fu-berlin.de/elc/bulletin/9/en/marsh.html

Steimberg, O. (1977). Leyendo historietas. Buenos Aires, Argentina: Nueva Visión. 
Spiegelman, A. (1986). Maus: A survivors tale: My father bleeds history. New York City, NY: Pantheon Books.

White, H. (1992). Historical emplotment and the problem of truth. In S. Friedlander (Ed.), Probing the limits of representation: Nazism and the 'Final Solution', pp. 37-53. Cambridge, MA: Harvard University Press.

White, H. (2003) Hecho y figuración en el discurso histórico. In Hayden White, El Texto histórico como artefacto literario y otros escritos, (Verónica Tozzi \& Nicolás Lavagnino, Trans.), pp. 43-62. Barcelona, Spain: Editorial Paidós.

\section{APPENDIX: CLIL LESSON PLAN}

\section{Aims:}

1. To learn about the so-called "Aryan race".

2. To understand the principles of this theory, how and why they were used for ideologically motivated racism in the Nazi Germany.

3. To analyse the historical context that allowed this theory to develop and become powerful in the Nazi German society.

4. To learn about the signs that make up the language of the comics: their conventional meanings and some other possible meanings that these signs can have in a comic strip.

5. To be able to identify and analyse how this theory of the perfect and pure race can be represented in an image: interpretation of the signs that make up a comic strip.

At the end of this unit, the students will be able to:

- Develop some critical analysis regarding the theory of the Aryan race through the conventions that make up the language of the comic.

\section{Curriculum:}

\section{Content:}

The theory of the Aryan Race: the notion of pure blood, perfect race, its effects on the Nazi German society and the historical reasons why this theory would become so popular and powerful. 


\section{Cognition}

- Identify the signs that make up the language of comics.

- Infer how these signs can get intertwined to allow the reader to have different possible interpretations of the same comic strip.

- Identify what signs in a given comic strip can give rise to plausible readings.

- Have a discussion about the situation that is being represented in a comic strip based on the power of the images illustrated and the words uttered by the characters.

- Associate a representation to some concept or principle of the "Aryan race".

- Associate different types of genre (the comic, fictional story, article): how the same content can be put across and illustrated.

- Identify and compare the most important issues of the content studied.

- Design an oral presentation in groups resorting to the web and software resources (previous revision of materials and sources).

- Write a personal appreciation of what has been learnt in the unit.

- Organize these contents in a personal portfolio.

\section{Communication}

\section{$\underline{\text { Language of learning }}$}

- Critical discourse analysis (CDA): analysis of arguments for and against a thesis.

- Specific vocabulary to the subject matter in question.

- Discourse connectors: describing a sequence of events.

Language for learning

- Strategies for reading and understanding a text.

- Strategies to improve classroom talk:

$\circ$ Encouraging student questioning.

- Surveying the class.

- Asking for oral review to encourage active listening and speaking. 
○ Mini presentations.

- Frames to facilitate debate.

- Language for analysis and conclusion (such as, "I have found out ...", "What I thought would happen was ...”).

Language through learning

- Vocabulary extension.

- Internet resources for new vocabulary and language.

\section{Culture}

- The theory of the "Aryan race".

- Representation of the Jews in the fine arts.

- Notion of victim and persecutor.

\section{Evaluation: Portfolio assessment}

The following are two sets of model activities which have been designed for the unit presented above, which might give rise to some other possible material designed.

\section{Set 1 (90 minutes): Introduction to the Holocaust}

In this lesson students will analyze the cover of the first volume of Maus, by Art Spiegelman, "My father bleeds history". The only information about Maus that the teacher is likely to give his/her students is that it is a famous cartoon that won the Pulitzer Prize in 1992. This cartoon is about the story of Vadlek Spiegelman, the father of Art Spiegelman (author and narrator) who is a Holocaust survivor. More information is likely to be given once the activities have been done, for the purpose of either confirming or rejecting students' predictions. A note to teachers about Maus is to be found in Appendix 1of that work.

The objectives of these activities are:

- To make students learn about the signs which make up the language of comics.

- To understand that the same sign can give rise to different interpretations. 
- To analyze how powerful images are in the actual transmission of meanings.

- To understand how images and words can complement each other in the transmission of knowledge and facts.

- The importance of the historical context to convey meaning through signs.

\section{Activity 1:}

Look at the cover of Maus, Vol. 1, by Art Spiegelman to answer the questions below:

1. What is this cartoon called? What do you think is the meaning of "Maus"? Why do you think the cartoon is called this?

2. What can you see in this picture? What do you think these animals represent?

3. Why do you think that the author (Art Spiegelman) has chosen animals to represent the characters in his story? Who do you think the mice represent? Why do you think that the swastika with the cat was drawn on a bright, white, full moon?

4. Look at the mice: what can you say about their physical appearance, age, clothes, body language? Are there any signs of expression on the mice's face? What might be the implication of selecting a big mouse and a small one?

5. Now look at the image of the cat face: Who does this cat remind you of? Account for your choice (they are likely to say "Hitler" because of the cat's hair and moustache).

6. Find in the internet the meaning of swastika and agree on one definition with your teacher and partners.

7. Now that you know who the cat is likely to represent and the meaning of the swastika, what would you say about the position of the swastika with the cat face on the moon, on top of the mice?

8. Besides the swastika, is there another sign that belongs to the Nazi Germany (if students do not know, the teacher should tell them that the "s" in the word Maus is depicted exactly the same way as the "S" of the SS ("SS" stood for Schutzstaffel, the Nazi paramilitary regiments, meaning "protection echelon"). 
9. Now, let's concentrate on the title, "My father bleeds history". Is there a word that tells you about a special colour? For example, the word "snow" lets you think of white, the word "sun" lets you think of yellow. (In this case, students should see that the word "bleed" allows the reader to think of colour red). Can you see this colour depicted somewhere on the cover? (It is present in the word Maus).

10. Finally, why do you think that the letters of the word Maus have pointed edges? (Different predictions which are consistent with the historical background should be accepted. One plausible interpretation is that these pointed edges stand for the barbed wire of the fences in the concentration camps.)

\section{Set 2 (90 minutes): The construction of Identity}

The main objective is:

- To make the students reflect on the importance of one's identity, one's name.

\section{Activity 1:}

1. Look at the cover of Yossel, by Jow Kubert.

2. In groups of three speak about what the following signs might signify:

- The grey and blue stripes.

- The kind of handwriting in the title.

- The date.

- The numbers on the person's forearm.

- The texture in the depiction of the hand.

Afterwards, some semiotic analysis will be done with the whole class. The stripes represent the victims' uniform. The texture in the depiction of the hand can illustrate the character's age; he is definitely not a child, and he is a male protagonist. The numbers connote lack of identity, the absence of a name. The victims wore a number, and they were listed not only for the sake of organization, to have a clear knowledge on the number of Jews in each concentration camp, but to deprive them of their identity. The kind of typography selected for the title reflects the character's job: he is a painter. The name Yossel might represent the painter's strokes on a wall. 
An interesting point to discuss is whether the story could have been based on a real character. This information can be checked in Yad Vashem Holocaust Museum (Jerusalem, Israel) database. ${ }^{1}$ The teacher should provide the students with the character's full name: Joe Kubert (Yossel is a nickname in Yiddish, traditional language of the German Jews). The museum's site provides different stories of different victims. If students feel motivated, they can, as an optional activity for their portfolios, do research on one of the persons on the database.

\section{Activity 2}

The purpose of this activity is to make students' imagine how the Holocaust victims could have felt when their names were replaced by numbers on their forearms. The notion that will be tackled is identity. Students will be made to reflect on their names and on those other names that they are actually given by others, names which can sometimes be quite discriminatory.

Which of the following concepts would you associate with the following terms? Why?

\section{LIBERATION - SENSE OF DESPAIR - LACK OF IDENTITY - SELECTION PROCESS - DEATH - HUMILLIATION}

The key term here is LACK OF IDENTITY.

Think about the following:

- Why did the Nazis deprived the Jews of their proper names?

- What is the importance of a name?

- Do you like your name? Do you know the meaning of your name? Do you think that your name reflects who you are, your character, your temper, your personality?

${ }^{1}$ http://www.yadvashem.org/. 


\section{BIODATA}

Livia Carolina RAvelo is a teacher of general and technical English at the Instituto Nacional Superior del Profesorado Técnico, UTN (Argentina). She holds a B.A. in English Language from the Universidad de Belgrano (Argentina) and a Master's degree in Discouse Analysis from the Universidad Nacional de Buenos Aires (Argentina). She also holds an M.A. in the teaching of Spanish and English as a foreign language from the Universidad de Jaén (Spain). She has vast experience in the teaching of English as a foreign language in primary, secondary, tertiary and university level in Argentina and in Israel and has worked as a teacher of Spanish as a foreign language at the Instituto Cervantes de Tel Aviv, Israel. At present, she is a lecturer in Technical English and Academic Writing at the Instituto Superior del Profesorado Joaquín V.González's Departamentos de Inglés y de Informática e Inglés in Buenos Aires (Argentina). 